\title{
The potential of synthetic biology for improving environmental quality and human health in developing countries
}

\section{Biologia Sintética: un nuevo potencial para mejorar la calidad ambiental y la salud humana en paises en desarrollo}

\author{
Miguel Fernández-Niño으, Zia-ul Islam²
}

Suggested citation: Fernández-Niño M, Islam Z. The potential of synthetic biology for improving environmental quality and human health in developing countries. Rev Univ Ind Santander Salud. 2017; 49(1): 93-101. DOI: http:/dx.doi.org/10.18273/ revsal.v49n1-2017009 (c) (i)

\begin{abstract}
Environmental quality is a major factor in global health that mainly affects the poorest populations. Vectorborne diseases, climate change, pollution and unintentional poisonings are recognized as the primary causes of environmental diseases burden in developing countries. The development and implementation of new technologies to reduce the impact of these risk factors on health in developing countries is a priority in the current research. In this regard, synthetic biology, a nearly new research area, has initiated a big revolution through the de novo design or rewiring of biological components, organisms, and functions with the aim to reduce the adverse effects of environmental risk factors on human health. Despite synthetic biology is well recognized for being a multidisciplinary area where biotechnologist, biologist, physicists, mathematicians and engineers play together, its integration with public health and other social sciences seems to be of relevance to apply these technologies into a practical context. In this review, we discuss the major advances in synthetic biology with potential to improve environmental quality and human health in developing countries.
\end{abstract}

Keywords: Public health. Synthetic biology. Developing countries. Environmental diseases.

\section{RESUMEN}

La calidad ambiental es reconocida como uno de los factores con mayor impacto sobre la salud humana principalmente en los países en vías de desarrollo. Las enfermedades transmitidas por vectores, el cambio climático, la contaminación y las intoxicaciones no intencionales han sido reportados como las principales causas de enfermedades ambientales en estos países. El desarrollo y la implementación de nuevas tecnologías encaminadas a reducir el impacto de estos factores ambientales en la salud es una prioridad de la investigación actual. En ese sentido, la biología sintética ha iniciado una gran revolución al permitir el diseño de novo y el mejoramiento de diversos componentes biológicos, organismos y funciones biológicas que tienen el potencial de reducir los efectos adversos de estos factores en la salud humana de una manera más eficiente y económica. A pesar de que la biología sintética es reconocida como un área multidisciplinaria donde biotecnólogos, biólogos, físicos, matemáticos e ingenieros unen sus esfuerzos, su

1. Jacobs University Bremen gGmbH, Bremen, Germany.

2. Abdul Wali Khan University, Mardan, Khyber Pakhtunkhwa, Pakistan.

Correspondence: Miguel Fernandez Niño. Address: Jacobs University Bremen gGmbH, Campus Ring 1 | 28759 Bremen, Germany. Email: m.fernandeznino@jacobs-university.de. Phone number: +49 4212003565 
integración con el área de la salud pública y las ciencias sociales es muy importante para llevar estas tecnologías a la práctica. En esta revisión, nosotros discutimos los más importantes avances en biología sintética y su potencial para mejorar la calidad ambiental y la salud humana en países en vías de desarrollo.

Keywords: Salud pública. Biología Sintética. Países en vías de desarrollo. Enfermedades ambientales.

\section{INTRODUCTION}

Almost 20 years ago, the role of the environmental quality as a determinant of human ill health was welldescribed by Kirk Smith and co-workers ${ }^{1}$. In their work summarized in the WHO 1997 report "Health and Environment in Sustainable Development," the authors attempted to establish a set of standard definitions and categories that were used over the last two decades to study how much the environmental factors are contributing to ill health. A formal definition of the terms "environment," "ill health" and "attributable" as well a defined number of diseases categories and environmental risk factors were provided and implemented to estimate the effect of several environment risk factor on the global ill health. The authors suggested that one-quarter to one-third of ill health in the world at that time was attributable to environmental factors ${ }^{1}$. Nevertheless, they also recognized that further collection of highquality global data related to the environmental health impact was needed to dissect this estimation properly.

During the past two decades, several studies were subsequently performed with the aim to increase the amount and quality of these data. Most of them implemented new tools for epidemiologic analysis, which resulted in more accurate methods for estimating the impact of the environmental factors on heath. A summary of these studies was published in 2008 by Prüss-Üstün and co-workers ${ }^{2}$. Authors performed a meta-synthesis analysis in order to integrate the results from a number of different studies originated in the various countries. In that way, the impact of several environmental factors on health was analyzed country-wise ${ }^{2}$. A total of 192 countries profiles were studied and data confirmed the previous hypothesis that environmental quality is a major factor in health that mainly affects the poorest populations ${ }^{1}$. People in developing countries have a higher risk due to the poor environmental quality ${ }^{2}$.

Nowadays, the United Nations Environment Programme (UNEP) and the World Health Organization (WHO) have established an initiative to facilitate and enhance effective actions in developing countries that can reduce the adverse environmental impact on human health. This initiative called "The Health, and Environment 94
Linkages" (HELI) has provided support to several developing countries focused on the major areas of risk defined in Table 1.

The development and implementation of new technologies to reduce the impact of these risk factors on health in developing countries is a priority in the current research (Table 1). In this regard, Synthetic Biology, a nearly new research area, has given a big step through the design of biological systems with the potential to reduce the adverse effects of environmental risk factors on human health. This nascent discipline has been extensively described and refers to a variety of experimental approaches (the product of interactive cycles of computer modeling, biology assembly, and testing) aimed to modify or mimic biological systems $^{15-20}$. In this review, we describe the major advances in synthetic biology with a highly potential to improve environmental quality and human health in developing countries.

Table 1. Priority causes of environmental diseases burden in developing countries

\begin{tabular}{|c|c|c|}
\hline Area of risk & Deaths globally per year & Reference \\
\hline \multirow{3}{*}{$\begin{array}{l}\text { Vector-borne } \\
\text { diseases }\end{array}$} & Malaria $\sim 1.2$ million & (3) \\
\hline & Leishmaniasis $\sim 30000$ & (4) \\
\hline & Dengue $\sim 10000$ & (5) \\
\hline $\begin{array}{l}\text { Climate change } \\
\text { impacts }\end{array}$ & $\sim 150000$ & $\begin{array}{l}(6) \\
(7)\end{array}$ \\
\hline \multirow{4}{*}{$\begin{array}{l}\text { Poor water } \\
\text { quality }\end{array}$} & $\begin{array}{l}\text { Diarrheal diseases } \sim 3 \\
\text { millions }\end{array}$ & \multirow{4}{*}{ (8) } \\
\hline & $\begin{array}{l}\text { Intestinal helminths } \sim 100 \\
000\end{array}$ & \\
\hline & Schistosomiasis $\sim 200000$ & \\
\hline & Trypanosomiasis $\sim 130000$ & \\
\hline $\begin{array}{l}\text { Poor urban and } \\
\text { indoor air quality }\end{array}$ & $\begin{array}{l}\text { Indoor smoke } \sim 1.6 \text { million } \\
\text { Urban air pollution } 800000\end{array}$ & $(9-10)$ \\
\hline $\begin{array}{l}\text { Unintentional } \\
\text { poisonings }\end{array}$ & $\begin{array}{l}\sim 585 \quad 000 \quad(355 \quad 000 \\
\text { associated with exposure } \\
\text { to toxic chemicals and } \\
\text { pesticides and } 230 \quad 000 \\
\text { associated to lead exposure) }\end{array}$ & $(11-14)$ \\
\hline
\end{tabular}


The potential of synthetic biology for improving environmental quality and human health in developing countries

\section{Synthetic Biology and human health}

According to König et al., synthetic biology can be defined as a rational approach to design new biological components, organisms, and functions that do not exist in nature or to redesign existing biological systems to satisfy human needs ${ }^{21}$. One of the most remarkable examples of the potential of synthetic biology in human health is the development of the semi-synthetic antimalarial drug artemisinin. Artemisinin, a sesquiterpene lactone endoperoxide extracted from the sweet wormwood plant (Artemisia апnиa) whose discovery was awarded the 2015 Nobel Prize is known to be very efficient against multidrugresistant Plasmodium $\operatorname{spp}^{22}$. This compound has been traditionally obtained from 8 months $A$. annua plants using well-described extraction methods ${ }^{23}$. For years, China and Vietnam lead the global production of this plant and more farmers around the world started to plant it due to its role in malaria treatment. However, its production was not enough to meet the demand, which made this drug unaffordable to most malaria sufferers as reported by Martin Enserink in $2005^{24}$. Just one year after Enserink's report, scientists from the University of California (Berkeley) published their 2006 Nature paper entitled "Production of the antimalarial drug precursor artemisinic acid in engineered yeast." Authors successfully engineered Saccharomyces cerevisiae to produce high titers of artemisinic acid (the immediate artemisinin precursor) in a cost-effective, eco-friendly and high-quality way ${ }^{25}$. First, the authors engineered the farnesyl pyrophosphate (FPP) biosynthetic pathway in order to increase the production of FPP and decrease its use for sterols by upregulating the expression of several genes in the FPP synthesis and downregulated those genes involved in FPP conversion to sterols. Then, they introduced and expressed the amorphadiene synthase gene (ADS) from the plant $A$. annua in $S$. cerevisiae to convert the FPP to amorphadiene. Finally, they cloned and expressed a novel cytochrome $\mathrm{P} 450$ from $A$. апnиa in $S$. cerevisiae that performs a three-step oxidation of amorphadiene to artemisinic acid ${ }^{25}$. Authors were able to engineered $S$. cerevisiae and subsequently produce artemisinic acid in a process with a higher specific productivity as compared to $A$. annua-based process using several synthetic biology approaches.

Only two years ago, in 2014, the production of artemisinic acid at industrial scale became real when a consortium within a synthetic biology company (Amyris, University of California, Berkeley) and the pharmaceutical firm Sanofi started to sell semisynthetic artemisinin made in genetically engineered yeast. They described this achievement as "a crucial breakthrough in anti-malaria efforts, particularly in terms of affordability and access for the poor." However, after two years in the market, the impact of the first commercial deployment of synthetic biology is very low, and there is still a long way to produce enough semi-synthetic artemisinin to replace the agriculturally produced $^{26}$.

Similar studies have been conducted to engineer Escherichia coli for artemisinic acid production ${ }^{27}$, to express synthetic human neutralizing antibodies against various dengue virus ${ }^{28}$, to construct a synthetic circuit for the enzyme inositol phosphoryl ceramide synthase in Leishmania $^{29}$ and to genetically-engineer Aedes aegypti mosquitoes to control the transmission of dengue ${ }^{30}$. All these examples show how synthetic biology approaches (based on cost-effective and eco-friendly technologies) can be used to improve the treatment of the major vectorborne diseases in developing countries. Nevertheless, as it was shown in the case of the artemisinin, an effective implementation of such technologies is a long and complex process, too long, that semi-synthetic artemisinin commercialization was concomitant with the observation of widespread artemisinin resistance across Southeast $\mathrm{Asia}^{31}$. In general, the complete process involves several phases of modeling and design, genetic and metabolic engineering, functional analysis, downstream processing, industrial application and marketing.

Despite Synthetic biology is well recognized for being a multidisciplinary area where biotechnologist, biologist, physicists, mathematicians and engineers play together, its integration with public health and other social sciences seems to be of relevance to rush the implementation of these technologies into a practical context.

\section{Synthetic biosensors and environmental quality}

Microbial bioindicators have been traditionally used for decades in order to estimate the altered environmental conditions and identify and quantify the effect of different pollutants in the environment ${ }^{32-33}$. Microorganisms have been mainly selected as bioindicators because they can be found in large quantities, which makes easier its detection and sampling. In addition, they contain a high number of quantifiable phenotypes induced by a large number of environmental alterations. There are several examples of bioindicators used to determine the quality of soil ${ }^{33}$, water ${ }^{32}$ and air $^{34}$.

Several advances in genetic and metabolic engineering during last two decades shifted the traditional use 
of microbial bio-indicators to engineered microbial biosensors able to recognize a particular analyte and transduce it into a detectable response ${ }^{35-38}$. For many years, a large number of biosensors have been constructed and implemented in various applications, ranging from public health, microbial ecology to environmental monitoring and food safety ${ }^{35}$. Microbial biosensors can be classified according to the type of signal that is detected after the interaction with the analyte including electrochemical ${ }^{39}$, thermal ${ }^{40}$, acoustic $^{41}$ and optical biosensors ${ }^{42}$.

Optical biosensors are the most commercially successful by far, and they are mainly based on the natural occurrence of bioluminescence observed in bacteria such as Vibrio fisheri ${ }^{43}$. Bioluminescence in the luminous marine bacteria Vibrio fisheri was described over 33 years ago as a phenome produced by Quorum Sensing $(\mathrm{QS})^{44}$. According to Miller and Bassler QS can be defined as the regulation of gene expression in response to fluctuation in cell population density ${ }^{45}$. Nowadays, a large number of studies have reported many phenotypes under control of Quorum Sensing including not only bioluminescence production but modulation of virulence factors ${ }^{46}$, symbiosis establishment ${ }^{47}$, genetic competence $^{48}$, antibiotic production ${ }^{49}$, motility ${ }^{50}$, sporulation $^{48}$ and biofilm formation ${ }^{51}$. QS Biosensors represent an alternative way of identification of several QS systems, which have profound implications in the healthcare and industry field.

Bioluminescent whole cell biosensors have also been developed using synthetic biology approaches since they are conceptually simple devices with a real-world application ${ }^{43}$. In addition, the increasing amount of input/output modalities available in the MIT Registry of Standard Biological Parts and a large number of models presented at the iGEM (the International Genetically Engineered Machine competition) allow a fairly quickly engineering process. The principles, devices, modules and methods employed to construct bioluminescent biosensors established the basis for designing novel biosensors for monitoring water, soil, and air quality.

In developing countries, poor water quality and unintentional poisonings are two leading causes of environmental diseases with a total of $\sim 3.5$ million and $\sim 600000$ deaths globally per year, respectively (Table 1). Several synthetic biosensors have designed to monitor the quality of water in an expensive, faster and the environmental-friendly way ${ }^{52}$. In general synthetic biosensors are composed by a reporter gene (fluorescent, luminescent or electrochemical), which is placed under the control of a promoter that is activated in the presence of a specific water contaminant ${ }^{53}$. Several biosensors that respond to $\operatorname{arsenic}^{54}$, cadmium ${ }^{55}$, mercury ${ }^{56}$, nitrogen ${ }^{57}$, ammonium $^{58}$, nitrate ${ }^{59}$, phosphorus ${ }^{60}$ and heavy metals have been reported ${ }^{53}$. These biosensors can detect water contaminants with sensitivities comparable to the conventional chemical/optical methods ${ }^{53}$.

One of the contaminants that to date is still circulating in groundwater causing more than 230000 deaths globally per year is lead (Table 1). Poisoning by this heavy metal remains the world's most common environmentally caused disease ${ }^{61}$. Remarkably, scientists of the National Taiwan University and the University of California have developed a highly selective fluorescent biosensor for detecting lead in living cells ${ }^{61-62}$. Authors have synthesized a Leadfluor-1 (LF1) turn-on sensor for selective detection of $\mathrm{Pb} 2+$ in water and living cells. Nevertheless, the authors conclude that more research is needed to standardize this method and subsequently implement it over the world.

In general, most of the current biosensors have been engineered in standard laboratory E. coli strains, which lack many of their physiological characteristics once they are placed in real environments. Consequently, most of the current research has shifted to the design of synthetic biosensors using native microorganism that inhabits the environment of interest ${ }^{53}$.

\section{Synthetic Biology against climate change}

The increase in world's population, as well as the global progressive trend in the development of industries, depends on energy in various forms. One important type of energy is the petroleum reserves. On the one hand, if these reserves are definite and in control of politically unstable countries, on the other hand, the use of this petro-based energy posed a serious threat to the climate in the form of global warming. In developing countries, this problem is more severe since there is a scarcity of resources to handle its hazardous waste streams. In this regard, the synthetic biology can provide a solution and has already provided an alternative to fossil fuels in the shape of biofuels such as bioethanol.

Bioethanol produced by natural $S$. cerevisiae strains from starch and sugar is the currently largest product in industrial biotechnology regarding market volume ${ }^{63}$. However, starch and sugar-containing plant biomass for example corn, cassava, sugar beet and sugar cane are usually employed as food or fodder ${ }^{64,65}$. As a consequence, the growing demand of industrial 
The potential of synthetic biology for improving environmental quality and human health in developing countries

biotechnology for carbon sources is feared to result in food shortage. Food security strongly requires a switch in industrial biotechnology towards renewable non-food carbon sources. In this regard, using nonedible lignocellulosic plant biomass is a possible route. Notably, the use of lignocellulose has also advantages compared to starch in terms of reduction of greenhouse gas emissions as shown by several studies in the field of bioethanol ${ }^{66,67}$. However, the utilization of lignocellulosic biomass generates several challenges at different levels. They mainly result from the complex nature of this feedstock and include (i) the requirement of harsh pretreatment methods ${ }^{68}$, (ii) complex and efficient enzyme mixtures for cellulose and hemicellulose hydrolysis produced in a costefficient way ${ }^{69,70}$ plus (iii) microorganisms able to efficiently ferment complex sugar mixtures (including pentose sugars) in the presence of toxic inhibitors in lignocellulosic hydrolysates.

An ideal fermentation organism for industrial implementation in lignocellulose-derived ethanol production is expected to be able to produce cellulases and hemicellulases for the hydrolysis of hemicellulose and cellulose to consolidate hydrolysis and fermentation steps $^{71}$. Although there have been many reports showing the expression of heterologous cellulolytic enzymes (e.g. endoglucanases and beta-glucosidases) in $S$. cerevisiae using synthetic biology approaches, the efficiency of cellulose and hemicellulose degradation by this way has not been sufficiently developed ${ }^{72-74}$.

A major challenge for lignocellulose-derived ethanol production results from the fact that the hydrolysis of lignocellulosic biomass into fermentable sugars is accompanied by the release of compounds that are inhibitory to microorganisms ${ }^{75}$. These compounds mainly result from degradation of hemicelluloses during pre-treatment and enzymatic hydrolysis. Different studies have been conducted for both reducing microbial inhibitors in the lignocellulosic hydrolysates ${ }^{76}$ and improving tolerance thought genetic and metabolic engineering.

One of the well-documented advantages of synthetic biology is its potential to valorize the waste stream from biofuels production. For instance, although the $\mathrm{CO}_{2}$ formed as a result of bioethanol formation, can be in principle taken up by plants via photosynthesis, but recently Schwander and coworkers (2016) developed a synthetic metabolic pathway that is even $20 \%$ more efficient than photosynthesis to fix the $\mathrm{CO}_{2}$ from the atmosphere. This technology will be very useful in developing countries and especially in those areas where the plants cannot grow due to the shortage of water or other factors. Another example is the biodiesel production via transesterification that generates $10 \%$ $(w / w)$ glycerol ${ }^{77}$. Glycerol can be used as a carbon source for growing different kind of engineered microorganisms to produce biochemical and proteins. One such example is the production of 1,3-propanediol from glycerol, which is used in cosmetics, polymers, lubricants, foods, and medicines ${ }^{78}$.

Another problem that is related to the use of fossil fuels is the release of harmful gasses in the air due to its combustion in engines. Acquiring expensive equipment and their maintenance to detect the levels of these harmful gasses in developing countries would not be feasible due to high cost. Very recently, a simplified biosensor was developed by an iGEM team (iGEM, 2016. inspector NO.CO.Li, Pakistan) that detects the levels of nitrogen oxide and carbon monoxide concentrations in the air. Various efforts in biotech sector have been dedicated to develop heat, cold, drought, and salinity-tolerant crops. These crops are anticipated to cope with the aftermath of climate change that results from global warming.

\section{Last generation methods for engineering biological systems}

The term synthetic biology dates back to $1910^{79}$. The first report that is regarded as a landmark in this regard was originated around $1961^{80}$. Later, the so-called pre-genomic era started between the 1970s and 1980s that mainly include the techniques such as molecular cloning and PCR. After this era, the synthetic biology field progressed with a faster pace. Especially, during the last decade i.e. since the mid of the 1990s, many techniques have been developed. For instance, RNAimediated gene knockdown, integration via homologous recombination, Zinc finger technology, transcriptionactivator-like effector nucleases (TALENs) and homing meganucleases. However, most of these methods have either low efficiency or results in off-target toxicity. Besides they are costly and time-consuming to engineer thus limiting their widespread use, particularly its application in developing countries where the resources are already very limited. Very recently, a new genome editing system called CRISPR-Cas9 was introduced and its potentiality to edit the genomes of human cells has been already reported ${ }^{81}$. This system has thrilled the synthetic biology community, and since then it has been used for genetic engineering of a variety of organisms. The reasons for its popularity are its accuracy and also 
the fact that it is cheaper and faster than the previous genome editing system. It is anticipated and currently seems like it will revolutionize the synthetic biology paradigm. The use of CRISPR-Cas9 might need laws and regulations in future to make the properly controlled use of this technology. These guidelines are regularly under development in developed countries. However, the formulations of new laws do not always guarantee the proper receiving of genetically modified organismbased products as the inhabitant of different parts of the world react differently to the modern biotechnology ${ }^{82}$. The use CRISPR-Cas9 for genome editing of plants and microorganisms is already in practice, and biotech companies around the world are quickly adopting it. The application of genome editing methods is crucial in solving the human health problems. In the health area, many unresolved health issues still exist in humans such as AIDS, hepatitis and different kinds of cancers. The transferable disease such is AIDS is creating much chaos in developing nations such is in Africa, where the awareness of the public and resources to handle its epidemic are less. Very recently, the first CRISPRCas9 based clinical trial was attempted in China for curing the lung cancer of a patient ${ }^{83}$. These developing countries also face the food shortage problem; that can also be addressed by application of these latest synthetic biology methods that can create robust crops as discussed above. In short, it will take time to reach the benefits or the customized CRISPR-Cas9 based genome editing methods to developing countries. Before its use in a routine way in these countries, laws and regulations needed to be developed, implemented and strictly observed.

\section{COMPETING INTERESTS}

The authors declare no competing financial interest.

\section{REFERENCES}

1. Smith KR, Corvalán CF, Kjellstrom T. How much global ill health is attributable to environmental factors? Epidemiology. 1999; 10: 573-584. DOI: 10.1097/01.ede.0000239647.26389.80.

2. Prüss-Üstün $\mathrm{A}$, Bonjour $\mathrm{S}$, Corvalán $\mathrm{C}$. The impact of the environment on health by country: a metasynthesis. Environ Health. 2008; (7): 7. DOI: 10.1186/1476-069X-7-7.

3. Alvar J, Vélez ID, Bern C, Herrero Mercé, Desjeux $\mathrm{P}$, Cano J, et al. Leishmaniasis Worldwide and Global Estimates of Its Incidence. PLoS ONE. 2012; 7(5): e35671. DOI: http://dx.doi.org/10.1371/ journal.pone. 0035671 .
4. Stanaway JD, Shepard D, Undurraga D, Halasa Y, Coffeng LE, Bradi OJ, et al. The global burden of dengue: an analysis from the Global Burden of Disease Study 2013. The Lancet. 2016; 16(6): 712-723. DOI: http://dx.doi.org/10.1016/S14733099(16)00026-8.

5. McMichael AJ, Woodruff RE. Climate change and human health. In Encyclopedia of World Climatology (ed John E. Oliver). 2005; 209-213.

6. The World health report 2002 - reducing risks, promoting healthy life. Geneva, World Health Organization, 2002.

7. Gleick PH. Dirty-water: estimated deaths from water-related diseases 2000-2020. The Pacific Institute Report. 2002.

8. Cohen AJ, Anderson R, Ostro B, Pandey KD, Krzyzanowski M, Künzli N, et al. The global burden of disease due to outdoor air pollution. J Toxicol Environ Health A. 2005; 68(13-14): 1301-1307. DOI: $10.1080 / 15287390590936166$.

9. Smith KR, Mehta S. The burden of disease from indoor air pollution in developing countries: comparison of estimates. Int J Hyg Environ Health. 2003; 206(4-5): 279-289. DOI: 10.1078/1438-463900224 .

10. The World health report 2003 - shaping the future. Geneva, World Health Organization, 2003.

11. Goldman, L, Tran, N. Toxics and poverty: the impact of toxic substances on the poor in developing countries. Washington, DC, The World Bank, 2002.

12. FAO/UNEP/WHO. Childhood pesticide poisoning: information for advocacy and action. Geneva, United Nations Environment Programme, 2004.

13. Fewtrell L, Kaufmann R, Prüss-Üstün, A. Lead: Assessing the environmental burden of disease at national and local level. WHO Environmental Burden of Disease Series. 2003; 54-55.

14. Drubin DA, Way JC, Silver PA. Designing biological systems. Genes Develop. 2007; 21:242-254. DOI: http://www.genesdev.org/cgi/doi/10.1101/ gad. 1507207.

15. Arkin AP. Synthetic cell biology. Curr Opin Biotechnol. 2001; 12: 638-644.

16. Benner SA, Sismour AM. Synthetic biology. Nat Rev Genet. 2005; 6(7): 533-543. DOI: 10.1038/ $\operatorname{nrg} 1637$.

17. McDaniel R, Weiss R. Advances in synthetic biology: on the path from prototypes to applications. Curr Opin Biotechnol. 2005; 16(4): 476-483. DOI: 10.1016/j.copbio.2005.07.002.

18. Andrianantoandro E, Basu S, Karig DK, Weiss R. Synthetic biology: new engineering rules for an emerging discipline. Mol Syst Biol. 2006; 2-14. 
The potential of synthetic biology for improving environmental quality and human health in developing countries

DOI: $10.1038 / \mathrm{msb} 4100073$.

19. De Lorenzo V, Danchin A. Synthetic biology: discovering new worlds and new words. The new and not so new aspects of this emerging research field. EMBO Rep. 2008; 9(9): 822-827. DOI: 10.1038/embor.2008.159.

20. König H, Frank D, Heil R, Coenen C. Synthetic genomics and synthetic biology applications between hopes and concerns. Curr Genomics. 2013; 14(1): 11-24.DOI: 10.2174/1389202911314010003.

21. Nosten F, White NJ. Artemisinin-Based Combination Treatment of Falciparum Malaria. In: Breman JG, Alilio MS, White NJ, editors. Defining and Defeating the Intolerable Burden of Malaria III: Progress and Perspectives: Supplement to Volume 77(6) of Am J Trop Med Hyg. Northbrook (IL): American Society of Tropical Medicine and Hygiene; 2007.

22. Lapkin AA, Peters M, Greiner L, Chemat S, Leonhard K, Liauw M, et al. Screening of new solvents for artemisinin extraction process using ab initio methodology. Green Chemistry. 2010; 12: 241-251. DOI: 10.1039/B922001A.

23. Enserink M. Source of new hope against malaria is in short supply. Science. 2005; 307(5706): 33. DOI: 10.1126/science.307.5706.33.

24. Ro DK, Paradise E, Ouellet M, Fisher K, Newman $\mathrm{K}$, Ndungu J, et al. Production of the antimalarial drug precursor artemisinic acid in engineered yeast. Nature. 2006; 440: 940-943. DOI: 10.1038/ nature 04640.

25. Peplow M. Synthetic biology's first malaria drug meets market resistance. Nature. 2016; 530(7591): 389-390. DOI: 10.1038/530390a.

26. Keasling JD. Synthetic biology and the development of tools for metabolic engineering. Metab Engineer. 2012; 14(3): 189-195. DOI: http://dx.doi. org/10.1016/j.ymben.2012.01.004.

27. Flingai S, Plummer E, Patel A, Shresta S, Mendoza J, Broderick K, et al. Protection against dengue disease by synthetic nucleic acid antibody prophylaxis / immunotherapy. Scientific reports. 2015; 5:12616. DOI: 10.1038/srep12616.

28. Mandlik V, Limbachiya D, Shinde S, Mol M, Singh S. Synthetic circuit of inositol phosphorylceramide synthase in Leishmania: a chemical biology approach. J Chem Biol. 2013; 6(2): 51-62. DOI: 10.1007/s12154-012-0089-7.

29. Wise de Valdez MR, Nimmo D, Betz J, Gong HF, James AA, Alphey L, et al. Genetic elimination of dengue vector mosquitoes. Proc Nati Acad Sci USA. 2011; 108(12): 4772-4775. DOI: 10.1073/ pnas. 1019295108 .
30. Ashley EA, Dhorda M, Fairhurst RM, Amaratunga C, Lim P, Suon S, et al. Spread of artemisinin resistance in Plasmodium falciparum malaria. N Engl J Med. 2014; 371: 411-423. DOI: 10.1056/ NEJMoa1314981.

31. Paerl HW, Dyble J, Moisander P, Noble R, Piehler $\mathrm{M}$, Pinckney $\mathrm{J}$, et al. Microbial indicators of aquatic ecosystem change: current applications to eutrophication studies. FEMS Micro Ecol. 2003; 46: 233-246. DOI: 10.1016/S0168-6496(03)00200-9.

32. Van Dorst J, Siciliano SD, Winsley T, Snape I, Ferrari BC. Bacterial Targets as Potential Indicators of Diesel Fuel Toxicity in Subantarctic Soils. Kostka JE, ed. Applied and Environmental Microbiology. 2014; 80(13): 4021-4033. DOI: 10.1128/AEM.03939-13.

33. Sumampouw OJ, Risjani, Y. Bacteria as indicators of environmental pollution: review. Int J Ecosys. 2014; 4:(6): 251-258. DOI: 10.5923/j.ije.20140406.03.

34. Su L, Jia W, Hou C, Lei Y. Microbial biosensors: a review. Biosens Bioelectron. 2011; 26(5): 17881799. DOI: 10.1016/j.bios.2010.09.005.

35. Belkin S. Microbial whole-cell sensing systems of environmental pollutants. Curr Opin Microbiol. 2003; 6: 206-212. DOI: 10.1016/S13695274(03)00059-6.

36. Lei Y, Chen W, Mulchandani A. Microbial biosensors. Anal Chim Acta. 2006; 568: 200-210. DOI: 10.1016/j.aca.2005.11.065.

37. Wilson, G. S. \& Gifford, R. Biosensors for real-time in vivo measurements. Biosens Bioelectron. 2005; 20: 2388-2403. DOI: 10.1016/j.bios.2004.12.003.

38. Grieshaber D, MacKenzie R, Vörös J, Reimhult E. Electrochemical Biosensors - Sensor Principles and Architectures. Sensors (Basel). 2008; 8(3): 14001458.

39. Ramanathan K, Danielsson B. Principles and applications of thermal biosensors. Biosens Bioelectron. 2001; 16: 417-423. DOI: 10.1016/ S0956-5663(01)00124-5.

40. Fogel R, Limson J, Seshia AA. Acoustic biosensors. Essays Biochem. 2016; 60(1): 101-110. DOI: 10.1042/EBC20150011.

41. Damborský P, Švitel J, Katrlík J. Optical biosensors. Essays in Biochemistry. 2016; 60(1): 91-100. DOI: 10.1042/EBC20150010.

42. French CE, de Mora K, Joshi N, Elfick A, Haseloff J, Ajioka J. A5 synthetic biology and the art of biosensor design. In: Institute of Medicine (US) Forum on Microbial Threats. The Science and Applications of Synthetic and Systems Biology: Workshop Summary. Washington (DC): National Academies Press (US); 2011. 
43. Nealson KH, Hastings JW. Bacterial bioluminescence: its control and ecological significance. Microbiol Rev. 1979; 43: 496-518.

44. Miller MB, Bassler BL. Quorum sensing in bacteria. Annu Rev Microbiol. 2001; 55: 165-199. DOI: 10.1146/annurev.micro.55.1.165.

45. Zhu J, Miller MB, Vance RE, Dziejman M, Bassler BL, Mekalanos JJ. Quorum-sensing regulators control virulence gene expression in Vibrio cholerae. Proc Natl Acad Sci. 2002; 99: 3129 -3134. DOI: $10.1073 /$ pnas.052694299.

46. Sanchez-Contreras M, Bauer WD, Gao M, Robinson JB, Downie AJ. Quorum-sensing regulation in rhizobia and its role in symbiotic interactions with legumes. Philos Trans R Soc Lond B Biol Sci. 2007; 362: 1149-1163. DOI: 10.1098/rstb.2007.2041.

47. Schultz D, Wolynes PG, Jacob EB, Onuchic JN. Deciding fate in adverse times: sporulation and competence in Bacillus subtilis. Proc Natl Acad Sci. 2009; 106: 21027-21034. DOI: 10.1073/ pnas.0912185106.

48. Thomson NR, Crow MA, McGowan SJ, Cox A, Salmond GP. Biosynthesis of carbapenem antibiotic and prodigiosin pigment in Serratia is under quorum sensing control. Mol Microbiol. 2000; 36: 539-556. DOI: 10.1046/j.1365-2958.2000.01872.x.

49. Hoang HH, Gurich N, Gonzalez JE. Regulation of Motility by the ExpR/Sin Quorum-Sensing System in Sinorhizobium meliloti. J Bacteriol. 2008; 190: 861-871. DOI: 10.1128/JB.01310-07.

50. Hammer BK, Bassler BL. Quorum sensing controls biofilm formation in Vibrio cholerae. Mol Microbiol. 2003; 50(1): 101-104. DOI: 10.1046/j.13652958.2003.03688.x.

51. Chouler J, Di Lorenzo M. Water quality monitoring in developing countries; can microbial fuel cells be the answer? Biosensors (Basel). 2015; 5(3): 450470. DOI: $10.3390 /$ bios5030450.

52. Aracic S, Manna S, Petrovski S, Wiltshire JL, Mann $\mathrm{G}$, Franks AE. Innovative biological approaches for monitoring and improving water quality. Front Microbiol. 2015; 6: 826. DOI: 10.3389/ fmicb.2015.00826.

53. Wang L, Jeon B, Sahin O, Zhang Q. Identification of an Arsenic Resistance and Arsenic-Sensing System in Campylobacter jejuni. Appl Environ Microbiol. 2009; 75(15): 5064-5073. DOI: 10.1128/ AEM.00149-09.

54. Goswami P, Das DK. A New highly sensitive and selective fluorescent cadmium sensor. J Fluoresc. 2012; 22: 391-395. DOI: 10.1007/s10895-0110971-7.

55. Bontidean I, Mortari A, Leth S, Brown NL, Karlson
$\mathrm{U}$, Larsen MM, et al. Biosensors for detection of mercury in contaminated soils. Environ Pollut. 2004; 131: 255-262. DOI: 10.1016/j.envpol.2004.02.019.

56. DeAngelis KM, Ji P, Firestone MK, Lindow SE. Two novel bacterial biosensors for detection of nitrate availability in the rhizosphere. Appl Environ Microbiol. 2005; 71(12): 8537-8547. DOI: 10.1128/ AEM.71.12.8537-8547.2005.

57. Raud M, Lember E, Jõgi E, Kikas T. Nitrosomonas sp. Based biosensor for ammonium nitrogen measurement in wastewater. Biotechnol Biopro Engine. 2013; 18: 1016-1021. DOI: 10.1007/ s12257-013-0078-x.

58. Prest AG, Winson MK, Hammond JR, Stewart GS. The construction and application of a lux-based nitrate biosensor. Lett Appl Microbiol. 1997; 24: 355-360. DOI: 10.1046/j.1472-765X.1997.00064.x.

59. Kulakova AN, Kulakov LA, McGrath JW, Quinn JP. The construction of a whole-cell biosensor for phosphonoacetate, based on the LysR-like transcriptional regulator PhnR from Pseudomonas fluorescens 23F. Microb Biotechnol. 2009; 2: 234240. DOI: 10.1111/j.1751-7915.2008.00082.x.

60. He Q, Miller EW, Wong AP, Chang CJ. A selective fluorescent sensor for detecting lead in living cells. J Am Chem Soc. 2006; 128(29): 9316-9317. DOI: 10.1021/ja063029x.

61. Chen CT, Huang WP. A highly selective fluorescent chemosensor for lead ions. J Am Chem Soc. 2002; 124: 6246-6247. DOI: 10.1021/ja025710e.

62. Nevoigt E. Progress in metabolic engineering of Saccharomyces cerevisiae. Microbiol Mol Biol Rev. 2008; 72(3): 379-412. DOI: 10.1128/MMBR.0002507.

63. Nikolić S, Mojović L, Rakin M, Pejin D. Bioethanol production from corn meal by simultaneous enzymatic saccharification and fermentation with immobilized cells of Saccharomyces cerevisiae var. ellipsoideus. Fuel 2009; 88(9): 1602-1607. DOI: 10.1016/j.fuel.2008.12.019.

64. Cardona C, Quintero J, Paz I. Production of bioethanol from sugarcane bagasse: status and perspectives. Bioresour Technol 2010; 101(13): 4754-4766. DOI: 10.1016/j.biortech.2009.10.097.

65. Lynd LR. Overview and evaluation of fuel ethanol from cellulosic biomass: technology, economics, the environment, and policy. Annu Rev Energy Environ 1996; 21(1): 403-465. DOI: 10.1146/annurev. energy.21.1.403.

66. Solomon BD, Barnes JR, Halvorsen KE. Grain and cellulosic ethanol: history, economics, and energy policy. Biom Bioen 2007; 31(6): 416-425. DOI: 10.1016/j.biombioe.2007.01.023. 
The potential of synthetic biology for improving environmental quality and human health in developing countries

67. Mosier N, Wyman C, Dale B, Elander R, Lee $\mathrm{Y}$, Holtzapple $\mathrm{M}$, et al. Features of promising technologies for pretreatment of lignocellulosic biomass. Bioresour Technol. 2005; 96(6): 673-686. DOI: 10.1016/j.biortech.2004.06.025.

68. Sternberg D. Production of cellulase by Trichoderma. Biotechnol Bioeng Symp. 1976; (6): 35-53.

69. Duff SJ, Murray WD. Bioconversion of forest products industry waste cellulosics to fuel ethanol: a review. Bioresour Technol. 1996; 55(1): 1-33. DOI : 10.1016/0960-8524(95)00122-0.

70. Olofsson K, Bertilsson M, Lidén G. A short review on $\mathrm{SSF}$-an interesting process option for ethanol production from lignocellulosic feedstocks. Biotechnology forbiofuels 2008; 1(1): 1-7. DOI: 10.1186/1754-6834-1-7.

71. Den Haan R, Rose SH, Lynd L. R, van Zyl W. H. Hydrolysis and fermentation of amorphous cellulose by recombinant Saccharomyces cerevisiae. Metab Eng. 2007; 9(1): 87-94. DOI: 10.1016/j. ymben.2006.08.005.

72. Baek S, Kim S, Lee K, Lee J, Hahn J. Cellulosic ethanol production by combination of cellulasedisplaying yeast cells. Enzyme Microb Technol. 2012; 51(6-7): 366-372. DOI: 10.1016/j. enzmictec.2012.08.005.

73. Yamada R, Nakatani Y, Ogino C, Kondo A. Efficient direct ethanol production from cellulose by cellulase-and cellodextrin transporter-co-expressing Saccharomyces cerevisiae. AMB Express 2013; 3(1): 1. DOI: 10.1186/2191-0855-3-34.

74. Olsson L, Hahn-Hägerdal B. Fermentation of lignocellulosic hydrolysates for ethanol production. Enzyme Microb Technol. 1996; 18(5): 312-331. DOI: 10.1016/0141-0229(95)00157-3.

75. Palmqvist E, Hahn-Hägerdal B. Fermentation of lignocellulosic hydrolysates. I: inhibition and detoxification. Bioresour Technol 2000; 74(1): 1724. DOI: 10.1016/S0960-8524(99)00160-1.

76. Ma F, Hanna MA. Biodiesel production: a review. Biores Technol. 1999; 70(1): 1-15. DOI: 10.1016/ S0960-8524(99)00025-5.

77. Mu Y, Teng H, Zhang D, Wang W, Xiu Z. Microbial production of 1,3-propanediol by Klebsiella pneumoniae using crude glycerol from biodiesel preparations. Biotechnol Lett. 2006; 28(21): 17551759. DOI: $10.1007 / \mathrm{s} 10529-006-9154-\mathrm{z}$.

78. González-Pajuelo M, Meynial-Salles I, Mendes F, Soucaille P, Vasconcelos I. Microbial Conversion of Glycerol to 1,3-Propanediol: physiological comparison of a natural producer, clostridium butyricum VPI 3266, and an Engineered Strain, Clostridium acetobutylicum DG1(pSPD5). Appl
Environ Microbiol. 2006; 72(1): 96-101. DOI: 10.1128/AEM.72.1.96-101.2006.

79. Monod J, Jacob F. Teleonomic mechanisms in cellular metabolism, growth, and differentiation. Cold Spring Harb Symp Quant Biol 1961; 26: 389401.

80. Mali P, Yang L, Esvelt K. M, Aach J, Guell M, DiCarlo JE, et al. RNA-guided human genome engineering via Cas9. Science. 2013; 15: 339(6121): 823-826. DOI: $10.1126 /$ science. 1232033 .

81. Kinderlerer J. Regulation of Biotechnology: Needs and Burdens in Developing Countries. Sheffield Institute of Biotechnological Law \& Ethics, University of Sheffield, Sheffield, UK 2002.

82. Cyranoski D. CRISPR gene-editing tested in a person for the first time. Nature. 2016; 539(7630): 479. DOI:10.1038/nature.2016.20988. 